\title{
Breeding strategies for developing transgenic white clover cultivars
}

\author{
D.R. WOODFIELD ${ }^{1}$ and D.W.R. WHITE ${ }^{2}$ \\ ${ }^{1}$ Plant Improvement, \\ ${ }^{2}$ Plant Molecular Genetics, \\ AgResearch Grasslands, Private Bag 11008, Palmerston North
}

\begin{abstract}
The introduction of foreign genes into elite white clover (Trifolium repens $\mathrm{L}$.) genotypes has resulted in the first field test of genetically modified white clover. We now require breeding strategies which efficiently deploy transgenes into commercial cultivars. Current white clover cultivars are synthetics, produced by randomly intermating selected parents or seed lines for up to 6 generations. Unfortunately, the uncontrolled nature of transgene insertion means each transformant has a different site of insertion and frequently has a variable number of inserts. This complicates breeding strategies because populations produced by intercrossing these transformants will contain multiple insertion sites, variable dosage at each insertion site, and be highly heterogeneous for expression level. A modified synthetic breeding method is proposed for cross-
\end{abstract} pollinated crops such as white clover which overcomes these difficulties by identifying $F_{2}$ progeny homozygous for a defined number of transgenes. These homozygotes are used as the parents to develop a synthetic with a specific genetic composition and high expression levels of the transgene in all progeny. The advantages of backcrossing into existing cultivars or directly transforming inbreds are also discussed. The initiation of new crossing programmes in successive years can be utilised to offset the initial lagphase until strategies which reduce the number of generations required to obtain commercial quantities are developed.

Keywords: backcrossing, breeding methods, cross-pollinated, hybrids, inbreeding, plant breeding, transgenic plants, Trifolium repens $\mathrm{L}$.

\section{Introduction}

Inserted single-gene traits provide unique variability that is either not present in a species, or has been difficult to develop using conventional breeding due to either low heritability or absence of a suitable screening technique. As a result genetically modified agricultural products are becoming a commercial reality with transgenic plant products approved for release in 9 different species (Table 1). The initial products released fall into five categories: herbicide resistance, insect resistance, delayed ripening, virus resistance, and altered quality.

The insertion of foreign genes has until very recently had little or no relevance to white clover cultivar development. Difficulties in obtaining a high frequency of transformation and regeneration (White \& Greenwood 1987; Parrott 1991), difficulties in achieving required expression levels (Ealing et al. 1994), and stringent quarantine requirements for transgenic plants, have made cultivar development purely academic. As yet no transgenic forage plants have been commercially

Table 1: Crop species for which genetically modified agricultural products are currently commercially available.

\begin{tabular}{|c|c|c|c|}
\hline Crop & Trait & Inserted gene & $\begin{array}{l}\text { Company/ } \\
\text { Country }\end{array}$ \\
\hline Tomato & $\begin{array}{l}\text { Delayed ripening } \\
\text { (Flavr Savr) }\end{array}$ & $\begin{array}{l}\text { Antisense } \\
\text { polygalacturonase }\end{array}$ & Calgene, USA \\
\hline Tomato & $\begin{array}{l}\text { Delayed ripening } \\
\text { (Endless summer) }\end{array}$ & $\begin{array}{l}\text { Gene controlling } \\
\text { ACC oxidase }\end{array}$ & $\begin{array}{l}\text { DNA Plant } \\
\text { Technology, USA }\end{array}$ \\
\hline Potato & $\begin{array}{l}\text { Colorado potato } \\
\text { beetle resistence }\end{array}$ & $\begin{array}{l}\text { Bacillus thuringiensis } \\
\text { gene encoding an } \\
\text { insecticidal toxin }\end{array}$ & Monsanto, USA \\
\hline Cotton & $\begin{array}{l}\text { Bromoxynil herbicide } \\
\text { resistance }\end{array}$ & $\begin{array}{l}\text { Bacterial gene encoding } \\
\text { nitrolase enzyme }\end{array}$ & Calgene, USA \\
\hline Maize & $\begin{array}{l}\text { European corn-borer } \\
\text { resistance }\end{array}$ & $\begin{array}{l}\text { Bacillus thuringiensis } \\
\text { gene encoding an } \\
\text { insecticidal toxin }\end{array}$ & $\begin{array}{l}\text { Mycogen/ } \\
\text { Ciba Geigy, USA }\end{array}$ \\
\hline Soybean & $\begin{array}{l}\text { Glyphosate herbicide } \\
\text { resistance }\end{array}$ & $\begin{array}{l}\text { Soil bacterium gene that } \\
\text { boosts photosynthesis }\end{array}$ & Monsanto, USA \\
\hline Squash & $\begin{array}{l}\text { Resistance to watermelon } \\
\text { mosaic virus and zuchini } \\
\text { yellow mosaic virus }\end{array}$ & $\begin{array}{l}\text { Two viral coat protein } \\
\text { genes }\end{array}$ & $\begin{array}{l}\text { Asgrow Seed } \\
\text { Company, USA }\end{array}$ \\
\hline Canola & $\begin{array}{l}\text { High lauric acid content } \\
\text { (a fatty acid used in soups) }\end{array}$ & $\begin{array}{l}\text { Thioesterase enzyme gene } \\
\text { from California bay tree }\end{array}$ & Calgene, USA \\
\hline Tobacco & $\begin{array}{l}\text { Tobacco mosaic virus } \\
\text { resistance }\end{array}$ & Viral coat protein gene & China \\
\hline Rice & Insect resistance & $\begin{array}{l}\text { Bacillus thuringiensis } \\
\text { gene encoding an } \\
\text { insecticidal toxin }\end{array}$ & China \\
\hline
\end{tabular}


released although field tests of genetically modified alfalfa and white clover are currently underway. The first field-release of transgenic white clover, containing a viral coat protein mediated resistance to white clover mosaic virus (WCIMV), was approved on 2 July 1995 and begun on 15 November 1995.

The advent of genetic engineering has not diminished the need for plant breeding (Bingham 1983; Figure 1). It is necessary to (i) screen a large population of primary transformants to identify those with high expression levels of the inserted gene, (ii) screen the progeny of these initial transformants for stable inheritance and consistently high expression levels, and (iii) identify genetic backgrounds which enhance expression level and have important agronomic characters such as high forage yield, seed yield and persistence. These phases are similar to initial steps followed in all plant improvement programmes and, like those in plant breeding, must be achieved before parents can be selected to develop a cultivar. These initial steps are certainly aided by the ability to monitor the inserted genes through molecular and biochemical means. Furthermore new breeding strategies are required to provide cultivars which have desired expression of the foreign gene. A combination of molecular genetics and plant breeding skills is required to achieve this successfully.

\section{White clover breeding behaviour}

White clover $(2 n=4 x=32)$ is predominantly an outcrossing species with 'diploid-like' (disomic) inheritance. Populations and cultivars are therefore a heterogeneous mixture of heterozygous individuals, resulting in high levels of genetic variation both within and among populations. This variability contributes to the broad environmental adaptation and phenotypic plasticity of white clover.

White clover has a gametophytic self-incompatibility system based on multiple alleles at the $\mathrm{S}$ locus which promotes outcrossing, but also has self-compatible alleles which can be used to develop inbreds (Williams 1987). Most outcrossing species carry a high genetic load of deleterious recessive alleles due to the high levels of heterozygosity and are either unable to be inbred or suffer from severe inbreeding depression. Development of transgenic cultivars in cross-pollinated species such as white clover is therefore more difficult than in species which have clonal, inbred or hybrid cultivars because efforts to deploy transgenes in a homozygous condition could also result in some inbreeding depression (Conner \& Christey 1994).

\section{Transformation and trait stabilisation}

Initial transformation and regeneration problems in white clover have been partially overcome by development of a system allowing direct insertion of foreign genes into a range of cultivars (White \& Voisey 1994; Voisey et al. 1994). Regeneration occurs via direct shoot formation (organogenesis) which avoids the undifferentiated cell phases involved in previous methods.

Plant transformation is unpredictable because transgene integration can occur throughout the genome as single or multiple copies and as full length, truncated, or rearranged versions. This means each transformant has a different site or sites of insertion and variable number of copies of each insert, along with variable function of some genes.

Expression levels are affected by the number of inserts and the gene dosage at each insertion site, with increasing gene dosage generally providing better expression levels (Hobbs et al. 1990; Hobbs et al. 1993; Smith et al. 1994). Other factors such as the site of insertion ("position effects"), methylation, and cosuppression contribute to the loss of function and lower than expected expression levels of transgenic proteins which are observed in some transgenic lines (Hobbs et al. 1990; Matzke \& Matzke 1993; Ealing et al. 1994). Thus many primary transformants may need to be screened to identify those individuals with adequate and stable expression levels.

For any breeding method to be successful it must control the copy number and overcome expression level constraints to provide stable and predictable expression levels. Stable inheritance of the transgenes must also be ensured and initial results in white clover have shown that both Mendelian and non-Mendelian inheritance can occur (Ealing et al. 1994; Scott et al. 1996).

\section{Conventional synthetic development}

Current white clover cultivars are synthetic varieties produced by crossing selected parental clones or seed lines. This requires up to 6 generations of multiplication to provide commercial quantities of seed, and is several generations beyond the point where maximum performance is expected. Parental numbers normally exceed 8 in white clover (Caradus \& Woodfield 1996) and should theoretically be above 16 (Allard 1960) and as many as 200 (Omolo \& Russell 1971) to prevent genetic drift and inbreeding. The requirement to maintain large population sizes differentiates cross-pollinated species from those with other breeding systems.

The uncontrolled nature of transgene insertion means each transformant has a different site of insertion. Using 
a conventional synthetic breeding scheme, populations produced by intercrossing primary transformants would contain multiple insertion sites, variable dosage at each insertion site, and have a highly heterogeneous expression level. If 16 genotypes were intercrossed, each possessing only a single insert, the final population could contain genotypes with 0 to 32 copies of the same transgene. While genotypes homozygous for a single transgene commonly have better expression than heterozygous genotypes, the presence of higher copy numbers can result in loss of expression (Matzke \& Matzke 1993).

The advantage of the standard synthetic approach is that it is convenient and simple for breeders, however, it is likely to give highly variable results even for a single transgene and would make pyramiding of several transgenes almost impossible. Two alternative methods which could be used immediately to provide homogeneous expression in synthetic cultivars are: (i) a modified synthetic with progeny testing and (ii) backcrossing into target cultivars with or without progeny testing.

\section{Modified synthetic development with progeny testing}

The modified synthetic approach involves introgression of a single transgene into a random mating population (Figure 1). A high expressing transformant containing a single insert would be crossed to at least 16 plants from the target population. Half or all of the resulting $F_{1}$ progenies contain a single copy of the transgene depending on whether the initial transformant was heterozygous or homozygous. Confirmed transgenic progeny would be intermated either within or among $\mathrm{F}_{1}$ families to provide $F_{2}$ populations segregating for 0 to 2 copies of the transgenic allele. At least 11 plants per $F_{2}$ family need to be screened for the transgene to have a 95\% probability of identifying one homozygous plant (Sedcole 1977). Progeny testing is required at this stage to identify homozygous individuals if no clear phenotypic differentiation between heterozygous and homozygous genotypes exists. Confirmed transgenic $\mathrm{F}_{2}$ plants would be test-crossed to a non-transgenic tester, and progeny tested for presence of the transgene. All test-cross progeny from homozygous $\mathrm{F}_{2}$ plants should contain the transgene. The confirmed homozygotes would then be intercrossed to produce a synthetic variety which should be homogeneous for two copies of a single insert (Figure 2).

This method controls the dosage of the transgene (and the linkage block in which it is located) but maintains the heterozygosity of the remainder of the
Figure 1: Steps involved in producing transgenic white clover cultivars.

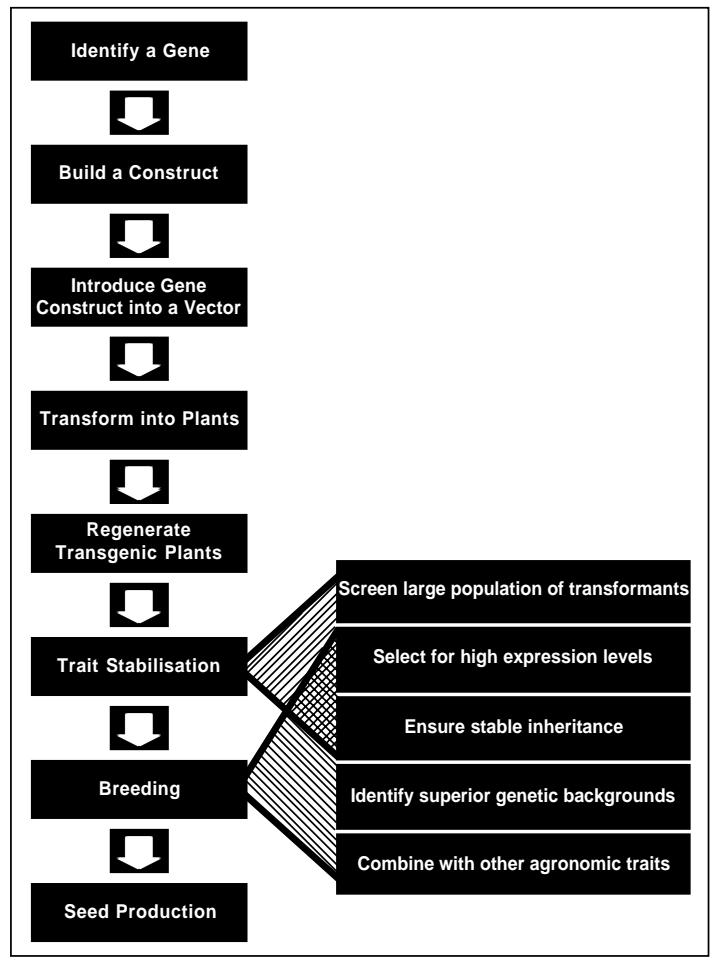

Figure 2: Modified synthetic breeding scheme for developing transgenic cultivars in cross-pollinated species such as white clover.

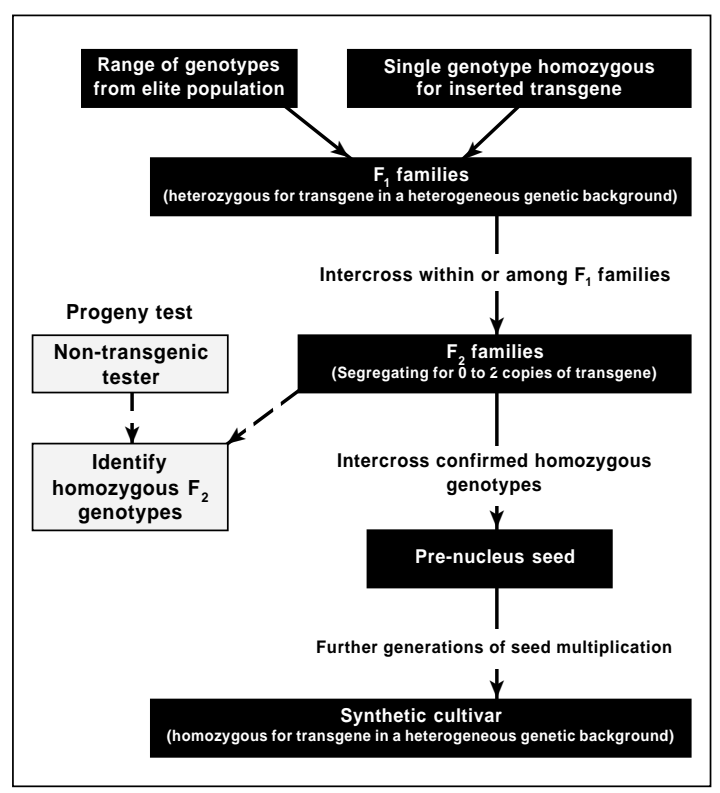


genome. This will provide more uniform expression than the standard synthetic approach but less uniform expression than in clonal, inbred or hybrid crops in which the genetic background remains fairly constant. There is some potential for inbreeding depression to occur because the whole linkage block in which the transgene is inserted will also be homozygous and this will need to be monitored on a case by case basis. This method is simple and complements existing breeding schemes in cross-pollinated crops but slows cultivar development because progeny testing is essential. Progeny testing for agronomic performance could run concurrently with identification of homozygous transgenic progeny to capitalise on the delay caused by this process.

This method can also be used without progeny testing in cases where maintaining non-transgenic or susceptible genotypes in a population is desired to avoid a breakdown in pest or disease resistance (i.e. $B t$ mediated insect resistance). In such cases a mixture of homozygous and heterozygous $\mathrm{F}_{2}$ genotypes would be intermated to produce a segregating synthetic cultivar.

\section{Backcrossing into elite cultivars}

The objective with backcrossing is to transfer a specific gene(s) into an otherwise desirable genetic background. This involves crossing a donor or non-recurrent parent containing the gene of interest to an elite population (recurrent parent), followed by several generations of backcrossing to this recurrent parent. At least five generations of backcrossing are required to regain approximately $97 \%$ of the recurrent parents' genetic background (Figure 3). In cross-pollinated crops it is essential to backcross to different genotypes of the recurrent parental population in each successive generation to avoid inbreeding depression.

Backcrossing maintains the transgene in a heterozygous condition. Therefore the transgene will be present in only $50 \%$ of the progeny in each generation and identification of transgenic progeny will be required for subsequent backcrossing. In the final backcross population confirmed transgenics will all be heterozygous for the transgene, and intercrossing confirmed heterozygotes will provide a population segregating for 0 to 2 copies of a single insert. Progeny testing and recombining confirmed homozygotes, as in the modified synthetic approach above, can be used to provide a population in which all individuals are homozygous for the transgene (Figure 3).

The main advantage of backcrossing is that a single transgene can be deployed into multiple genetic backgrounds at a lower cost than is likely with direct transformation into each background. The agronomic
Figure 3: Scheme for backcrossing transgenic traits into existing cultivars or elite populations (different genotypes from recurrent parental population used for each backcross generation).

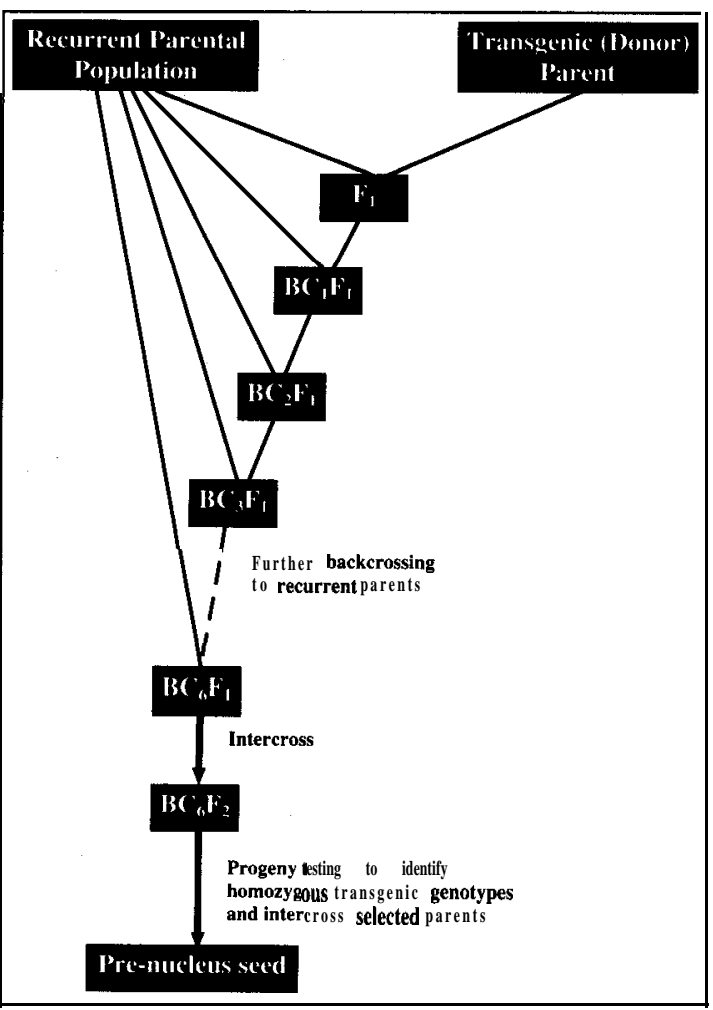

performance of the final product(s) should be fairly predictable and PVR may also be simplified, depending on the distinctiveness of the inserted gene. The main disadvantage is the additional 5 to 6 generations of backcrossing and progeny screening required.

\section{Direct transformation of inbred lines}

Severe inbreeding depression and some hybrid vigour have been reported in white clover (Williams 1987), however, the identification of self-compatible genotypes in white clover offers the potential to produce hybrid cultivars and/or near-isogenic lines for experimental use. Hybrid cultivars have several advantages over synthetics for transgenic deployment including: (i) fewer generations of multiplication are required, (ii) nonadditive gene action is fully utilised and both general and specific combining ability can be capitalised on, (iii) maximum population uniformity and uniform trait expression occurs, and (iv) there is less opportunity for transgene escape during multiplication. Furthermore the 
higher yield and better environmental stability of hybrids should provide a marked advantage over traditional synthetic varieties (Stuber 1994).

Pollination control mechanisms are required. White clover has complete flowers and as yet no male sterility has been identified. The gametophytic self-incompatibility system in white clover remains the most feasible mechanism for pollination control. Breeding schemes for producing hybrids using self-incompatibility have been described by Williams (1987), Taylor (1987) and Yamada et al. (1989).

Direct transformation of partial inbreds $\left(\mathrm{S}_{2}\right.$ or $\mathrm{S}$, ) would allow trait stabilisation during subsequent inbreeding to $S_{5}$ or $S_{6}(F=0.98)$. Inbreds with high expression of one or more transgenes could be combined during hybrid production to get the desired expression levels of a combination of genes in the final cultivar. This may be hampered by difficulties in getting sufficient numbers of primary transformants when using the less vigorous $S_{2}$ and $S_{3}$ plants.

\section{Commercial issues}

Several commercial issues relating to transgenic cultivars need to be considered including the number of cultivars which can be sustained, the length of the development phase, the expected life of the cultivar, and the ability to produce cultivars with multiple transgenic traits.

Currently 38 cultivars are being multiplied in New Zealand (Clifford et al. 1996) and over 90 cultivars are currently certified by OECD (Mather et al. 1996). As this is approaching market saturation, transgenic cultivars must show a clear agronomic advantage in order to replace cultivars being multiplied here (Clifford et al. 1996), and to replace overseas cultivars marketed internationally.
The cost of producing transgenic cultivars is likely to be higher than those produced by standard methods. The additional cost of transformation, trait stabilisation and initial progeny testing means that a transgenic cultivar must either achieve a higher market share or maintain its market share over a longer duration than a conventional synthetic for a commercial company to return a profit on its investment. While the first transgenic white clover cultivars will probably contain a single transgene, subsequent releases will probably need to contain several traits to ensure an adequate life expectancy. For both genetic and economic reasons breeding strategies which reduce the number of multiplication generations will be advantageous.

The apparent lag time between initiating a new breeding programme and producing the final cultivar can be offset by establishing a sequential programme whereby a new trait or combination of traits is entered each year and runs concurrently with the initial programme (Figure 4). This applies equally to starting development of different types of cultivars for different markets (e.g. dairy versus sheep, and national versus international). Thus after an initial lag-phase a new cultivar(s) is produced each year thereafter. There are some efficiencies of scale that can be gained this way, and genes can be pyramided in a logical and progressive manner to provide incremental improvements in performance.

\section{References}

\section{Allard, R.W. 1960. Principles of Plant B reeding. John Wiley and Sons, New York. \\ Bingham, E.T. 1983. Molecular genetic engineering vs plant breeding. Plant Molecular Biology 2: 222- 224.}

Figure 4: Theoretical systematic deployment of transgenic white clover cultivars based on modified synthetic development with progeny testing.

\begin{tabular}{|c|c|c|c|c|c|c|c|c|c|c|c|c|c|c|}
\hline & ear 1 & 2 & 3 & 4 & 5 & 6 & 7 & 8 & 9 & 10 & \multirow[t]{2}{*}{11} & \multirow[t]{3}{*}{12} & \multirow[t]{4}{*}{13} & \multirow[t]{5}{*}{14} \\
\hline AMV & Transform & $\begin{array}{l}\text { Stabilise } \\
\text { Trait }\end{array}$ & $\begin{array}{c}\text { Produce } \\
\text { FI }^{\prime}\end{array}$ & $\begin{array}{c}\text { Produce } \\
F_{\mathbf{r}}\end{array}$ & $\begin{array}{c}\text { Prokeny } \\
\text { Test }\end{array}$ & Intercross & $\begin{array}{l}\text { Pre- } \\
\text { nucleus }\end{array}$ & Nucleus & Breeders & Busce & & & & \\
\hline & \multirow[t]{4}{*}{$\mathbf{W C M V}$} & Transform & $\begin{array}{c}\text { Stabilise } \\
\text { Trait }\end{array}$ & Produce & $\begin{array}{l}\text { Produce } \\
\qquad \mathrm{F}_{2}\end{array}$ & $\begin{array}{c}\text { Proeeny } \\
\text { Test }\end{array}$ & Intercross & $\begin{array}{l}\text { Pre } \\
\text { nucleus }\end{array}$ & Nucleus & Breeders & Basic & & & \\
\hline & & Bt toxin & Transform & $\begin{array}{c}\text { Stabilise } \\
\text { Truit }\end{array}$ & $\begin{array}{c}\text { Produce } \\
\text { F }_{1}\end{array}$ & $\begin{array}{c}\text { Produce } \\
\quad F_{2}\end{array}$ & $\begin{array}{c}\text { Progeny } \\
\text { Test }\end{array}$ & Intercross & $\begin{array}{l}\text { Pre- } \\
\text { nucleus }\end{array}$ & Nucleus & Breeders & Basic & & \\
\hline & & \multicolumn{2}{|c|}{ S-rich protcins } & Transform & $\begin{array}{l}\text { Stabilise } \\
\text { Truit }\end{array}$ & $\begin{array}{c}\text { Produce } \\
\text { F }_{1}\end{array}$ & $\begin{array}{c}\text { Produce } \\
\mathrm{F}_{2}\end{array}$ & $\begin{array}{l}\text { Progeny } \\
\text { Test }\end{array}$ & Intercross & $\begin{array}{l}\text { Pre- } \\
\text { nucleus }\end{array}$ & Nucleus & Breeders & Basic & \\
\hline & & & AMV & + WCMV & Trumaromin & $\begin{array}{c}\text { Stabillise } \\
\text { Trait }\end{array}$ & $\begin{array}{c}\text { Routine } \\
F_{1}\end{array}$ & $\underset{F_{2}}{M}$ & $\begin{array}{c}\text { Nörona } \\
\text { Test }\end{array}$ & Inosecrom & $\begin{array}{l}\text { Pro } \\
\text { nucleus }\end{array}$ & Nuolowe & Broudore & 20 \\
\hline
\end{tabular}


Caradus, J.R.; Woodfield, D.R. 1996. World checklist of white clover varieties II. New Zealand Journal Agricultural Research (submitted).

Clifford, P.T.P.; Sparks, G.A.; Woodfield, D.R. 1996. The intensifying requirements for white clover cultivar change. Agronomy Society of New Zealand Special Publi-cation No. 11/Grassland Research and Practice Series No. 6: 19-24.

Conner, A.J.; Christey, M.C. 1994. Plant breeding and seed marketing options for the introduction of transgenic insect-resistant crops. Biocontrol Science and Technology 4: 463-473.

Ealing, P.M.; Hancock, K.R.; White, D.W.R. 1994. Expression of the pea albumin 1 gene in transgenic white clover and tobacco. Transgenic Research 3: 344-354.

Hobbs, S.L.A.; Warkentin, T.D.; DeLong, C.M.O. 1993. Transgene copy number can be positively and negatively associated with transgene expression. Plant Molecular Biology 21: 17-26.

Hobbs, S.L.A.; Kpodar, P.; DeLong, C.M.O. 1990. The effect of T-DNA copy number, position and methylation on reporter gene expression in tobacco transformants. Plant Molecular Biology 15: 851864.

Mather, R.D.J.; Melhuish, D.T.; Herlihy, M. 1996. Trends in the global marketing of white clover cultivars. Agronomy Society of New Zealand Special Publication No. 11/Grassland Research and Practice Series No. 6: 7-14.

Matzke, M.A.; Matzke, A.J.M. 1993. Genomic imprinting in plants: Parental effects and transinactivation phenomena. Annual Review Plant Physiology and Plant Molecular Biology 44: 5376.

Omolo, E.; Russell, W.A. 1971. Genetic effects of population size in the reproduction of two heterogeneous maize populations. Iowa State Journal Science 45: 499-512.

Parrott, W.A. 1991. Auxin-stimulated somatic embryogenesis from immature cotyledons of white clover. Plant Cell Reports 10: 17-21.
Scott, A.G.; Woodfield, D.R.; Allan, A.; Maher, D.; White, D.W.R. 1996. Inheritance and expression of transgenes in white clover. Agronomy Society of New Zealand Special Publication No. 11/Grassland Research and Practice Series No. 6: 131-135.

Sedcole, J.R. 1977. Number of plants necessary to recover a trait. Crop Science 17: 667-668.

Smith, H.A.; Swaney, S.L.; Parks, T.D.; Wernsman, E.A.; Dougherty, W.G. 1994. Transgenic plant virus resistance mediated by untranslatable sense RNAs: Expression, regulation, and fate of nonessential RNAs. The Plant Cell 6: 1441-1453.

Stuber, C.W. 1994. Heterosis in plant breeding. Plant Breeding Reviews 12: 227-251.

Taylor, N.L. 1987. Forage legumes. pp. 209-248. In: Fehr, W.R. (ed.). Principles of Cultivar Development. Volume 2. Crop species. Macmillan Publ. Company, New York.

Voisey, C.R.; White, D.W.R.; Dudas, B.; Appleby, R.D.; Ealing, P.M.; Scott, A.G. 1994. Agrobacteriummediated transformation of white clover using direct shoot organogenesis. Plant Cell Reports 13: 309314.

White, D.W.R.; Greenwood, D. 1987. Transformation of the forage legume Trifolium repens L. using binary Agrobacterium vectors. Plant Molecular Biology 8: 461-469.

White, D.W.R.; Voisey, C.R. 1994. Prolific direct plant regeneration from cotyledons of white clover. Plant Cell Reports 13: 303-308.

Williams, W.M. 1987. Genetics and breeding. pp. 343419. In: Baker, M.J.; Williams, W.M. (eds). White Clover. CAB International, Wallingford, U.K.

Yamada, T.; Fukuoka, H.; Wakamatsu, T. 1989. Recurrent selection of white clover (Trifolium repens L.) using self-compatibility factor. Proceedings International Grassland Congress 16: 299-300. 